\title{
Effect of ocean acidification on microbial diversity and on microbe-driven biogeochemistry and ecosystem functioning
}

\author{
Jinwen Liu ${ }^{1,2,3}$, Markus G. Weinbauer ${ }^{1,2}$, Cornelia Maier $^{1,2}$, Minhan Dai $^{3}$, \\ Jean-Pierre Gattuso ${ }^{1,2, *}$
}

${ }^{1}$ INSU-CNRS, Laboratoire d'Océanographie de Villefranche, BP 28, 06234 Villefranche-sur-mer Cedex, France ${ }^{2}$ Université Pierre et Marie Curie, Observatoire Océanologique de Villefranche, 06230 Villefranche-sur-mer, France ${ }^{3}$ State Key Laboratory of Marine Environmental Science, Xiamen University, 361005 Xiamen, China

\begin{abstract}
The ocean absorbs about $25 \%$ of anthropogenic $\mathrm{CO}_{2}$ emissions, which alters its chemistry. Among the changes of the carbonate system are an increase in the partial pressure of $\mathrm{CO}_{2}$ $\left(\mathrm{pCO}_{2}\right)$ and a decline of $\mathrm{pH}$; hence, the whole process is often referred to as 'ocean acidification'. Many microbial processes can be affected either directly or indirectly via a cascade of effects through the response of non-microbial groups and/or through changes in seawater chemistry. We briefly review the current understanding of the impact of ocean acidification on microbial diversity and processes, and highlight the gaps that need to be addressed in future research. The focus is on Bacteria, Archaea, viruses and protistan grazers but also includes total primary production of phytoplankton as well as species composition of eukaryotic phytoplankton. Some species and communities exhibit increased primary production at elevated $\mathrm{pCO}_{2}$. In contrast to their heterocystous counterparts, nitrogen fixation by non-heterocystous cyanobacteria is stimulated by elevated $\mathrm{pCO}_{2}$. The experimental data on the response of prokaryotic production to ocean acidification are not consistent. Very few other microbial processes have been investigated at environmentally relevant $\mathrm{pH}$ levels. The potential for microbes to adapt to ocean acidification, at either the species level by genetic change or at the community level through the replacement of sensitive species or groups by non- or less sensitive ones, is completely unknown. Consequently, the impact of ocean acidification on keystone species and microbial diversity needs to be elucidated. Most experiments used a short-term perturbation approach by using cultured organisms; few were conducted in mesocosms and none in situ. There is likely a lot to be learned from observations in areas naturally enriched with $\mathrm{CO}_{2}$, such as vents, upwelling and near-shore areas.
\end{abstract}

KEY WORDS: Ocean acidification $\cdot$ Microbial diversity $\cdot$ Microbe $\cdot$ Bacteria $\cdot$ Phytoplankton $\cdot$ Viruses Biogeochemistry · Meta-analysis

\section{INTRODUCTION}

The partial pressure of carbon dioxide $\left(\mathrm{pCO}_{2}\right)$ increases in the atmosphere due to the anthropogenic input of $\mathrm{CO}_{2}$ through the burning of fossil fuel, cement production and land-use change. It has increased by $32 \%$ between 1880 and 2000 (280 to 379 uatm; Solomon et al. 2007), leading to changes in the Earth's climate and the functioning of terrestrial ecosystems. Over the past $250 \mathrm{yr}$, the world's oceans have absorbed about one-third of the anthropogenic $\mathrm{CO}_{2}$, which is now distributed from the surface to depths ranging from a few hundred to a few thousand metres (Sabine et al. 2004). The uptake of anthropogenic $\mathrm{CO}_{2}$ profoundly affects the parameters of the carbonate chemistry (e.g. Gattuso \& Lavigne 2009), leading to an increase of $\mathrm{pCO}_{2}$ and of the concentrations of dissolved inorganic carbon (DIC) and bicarbonate ions $\left(\mathrm{HCO}_{3}{ }^{-}\right)$, as well as to a decrease of $\mathrm{pH}$ and of the concentration of carbonate ions $\left(\mathrm{CO}_{3}{ }^{2-}\right)$. The term 'ocean acidifica- 
tion' (Caldeira \& Wickett 2003) relates to the decrease in $\mathrm{pH}$ but does not imply that the $\mathrm{pH}$ of ocean surface waters will become acidic (i.e. below 7) any time soon.

If the current trends in $\mathrm{CO}_{2}$ emissions continue to increase, the $\mathrm{pH}$ of the global surface ocean could decrease by about 0.4 units by the end of the century compared to pre-industrial times. Changes will be more pronounced in areas such as the Southern Ocean, which will become undersaturated with respect to aragonite in 2050 (Orr et al. 2005), and the Arctic Ocean where aragonite undersaturation will occur even sooner (Steinacher et al. 2009). This change in the chemistry of the oceans is quantifiable and predictable for a given level of atmospheric $\mathrm{pCO}_{2}$. Observations at several time-series stations, even though all of them relatively short $(<20 \mathrm{yr})$, confirm the predicted changes in the carbonate chemistry (e.g. Santana-Casiano et al. 2007).

The biological, ecological and biogeochemical responses of marine organisms and communities have only been actively studied in the past few years, and there is still a high level of uncertainty and debate on the significance and magnitude of those responses (Hendriks et al. 2010, Dupont et al. 2010). A metaanalysis of the response of marine organisms to ocean acidification recently performed by Hendriks et al. (2010) only partly covers microbial groups and microbial biogeochemistry. Marine microbes, here considered as single-celled organisms (i.e. prokaryotes and protists) and viruses, are very diverse, as they thrive in a large range of habitats and perform a wide range of functions. They are therefore involved in virtually all geochemical reactions occurring in the oceans (Kirchman 2008). Some of these functions are even exclusively performed by prokaryotes. Some prokaryotes are able to withstand extreme $\mathrm{pH}$ values with optimal $\mathrm{pH}$ for growth ranging from 0.7 to $>10$ (Cavicchioli 2002).

The microbial group that has been investigated most thoroughly with respect to the effect of ocean acidification is eukaryotic phytoplankton (Riebesell 2004, Giordano et al. 2005, Beardall et al. 2009). In contrast, other groups such as viruses, Archaea, Bacteria and heterotrophic protists have received considerably less attention. In a recent 'perspective' paper, Joint et al. (in press) asked 'Will ocean acidification affect marine microbes?' In a narrative (sensu Gates 2002) review, Joint et al. (in press) looked at some of the relevant literature and came to the conclusion that 'perhaps the most appropriate null hypothesis to test is that marine microbes possess the flexibility to accommodate $\mathrm{pH}$ change and there will be no catastrophic changes in marine biogeochemical processes that are driven by phytoplankton, bacteria and archaea' and recognised that calcification and photosynthesis could be affected. Narrative reviews have the potential for serious bias, which could lead to misleading conclusions (Gates
2002). Meta-analysis was developed to overcome most biases of narrative reviews. It statistically combines the results (effect size) of several studies that address a shared research hypothesis.

Here we used a meta-analytic approach to comprehensively review the current understanding of the effect of ocean acidification on microbes and microbial processes, and to highlight the gaps that need to be addressed in future research.

\section{METHODS}

Data were collected from the EPOCA/EUROCEANS database (Nisumaa et al. 2010), the tables or text of papers, or interpolated from figures. Only papers reporting the effect of elevated $\mathrm{pCO}_{2}$ or decreased $\mathrm{pH}$ in the range of values expected during the period spanning the last glacial maximum and the year 2100 were selected. Unless mentioned otherwise, $\mathrm{pH}$ values are reported on the total scale (Dickson 2010). $\mathrm{pCO}_{2}$ levels were calculated from $\mathrm{pH}$ and other ancillary data with the R software package seacarb (Lavigne \& Gattuso 2010) as described by Nisumaa et al. (2010). Data permitting, 2 effect sizes were calculated for each variable: $\mathrm{H}: \mathrm{C}$, the value at high $\mathrm{pCO}_{2}$ versus the value at control $\mathrm{pCO}_{2}$; and $\mathrm{C}: \mathrm{L}$, the value at control $\mathrm{pCO}_{2}$ versus the value at low $\mathrm{pCO}_{2}$. The ranges of high $(\mathrm{H})$, control $(\mathrm{C})$ and low (L) $\mathrm{pCO}_{2}$ were 450 to 1500,300 to 450 and 100 to $300 \mu \mathrm{atm}$, respectively. These levels roughly correspond to 'future', 'present' and 'glacial' conditions. For mesocosm experiments, in which $\mathrm{pCO}_{2}$ was drifting, the data were categorised into the 'low', 'control' and 'high' $\mathrm{pCO}_{2}$ categories according to the $\mathrm{pCO}_{2}$ values at the beginning of the time period considered. Only the data collected during the pre-bloom phase of mesocosm experiments were used because the termination of the blooms may have distinct causes in addition to nutrient exhaustion (e.g. viral lysis): Days 5 to 14 for PeECE I (Engel et al. 2005), Days 0 to 14 for PeECE II (Grossart et al. 2006a) and Days 6 to 9 for PeECE III (Riebesell et al. 2008). There are 2 exceptions. The community respiration data reported by Egge et al. (2009) exhibit a large day-to-day variability and only Day 8 was considered. Tanaka et al. (2008) did not report alkaline phosphatase activity data for Days 6 to 9; hence data from Days 13 to 19 were used. The effect size is shown in Fig. 1 (see Fig. 1 in 'Results'. It is important to note that the effect is monotonous when $\mathrm{H}: \mathrm{C}$ and L:C are both above or below 1, whereas the effect exhibits an extreme when one of the effects is above 1 and the other below 1 .

Meta-analyses were performed with the $\mathrm{R}$ package meta 1.1.8 (Schwarzer 2010) to test the significance of the effect sizes H:C and L:C. The results are shown in Tables $1 \& 2$. Fixed and random effects models can be 
used in a meta-analysis (Borenstein et al. 2009). The fixed effect model generally assumes that all studies shared a single effect, whereas the effect could be different from study to study in the random effects model. There is no reason to assume that ocean acidification has the same effect on a variable measured in different species and/or under different experimental conditions. However, some have argued that the fixed effect method is valid without assuming a common true effect size (Borenstein et al. 2009); hence, both models were used. Inverse variance weighting was used for pooling and the DerSimonian-Laird estimate was used in the random effects model. Hedges' adjusted $g$ was applied to calculate the standardised mean difference (SMD). The heterogeneity of responses with a random effects model was assessed using the $Q$ statistics as well as with the $H$ and $I^{2}$ indices (Borenstein et al. 2009). $I^{2}$ is 0 when all variability in effect size estimates is due to sampling error within studies; $I^{2}$ values of 25 , 50 and $75 \%$ correspond to mean low, medium and high heterogeneity, respectively. When $H<1.2$, there is no heterogeneity within the studies, while there are obvious differences between studies when $H>1.5$.

\section{pH REGULATION}

Marine microbes have an optimum $\mathrm{pH}$ range that varies between species, and many physiological processes are $\mathrm{pH}$-dependent. It is therefore critical that

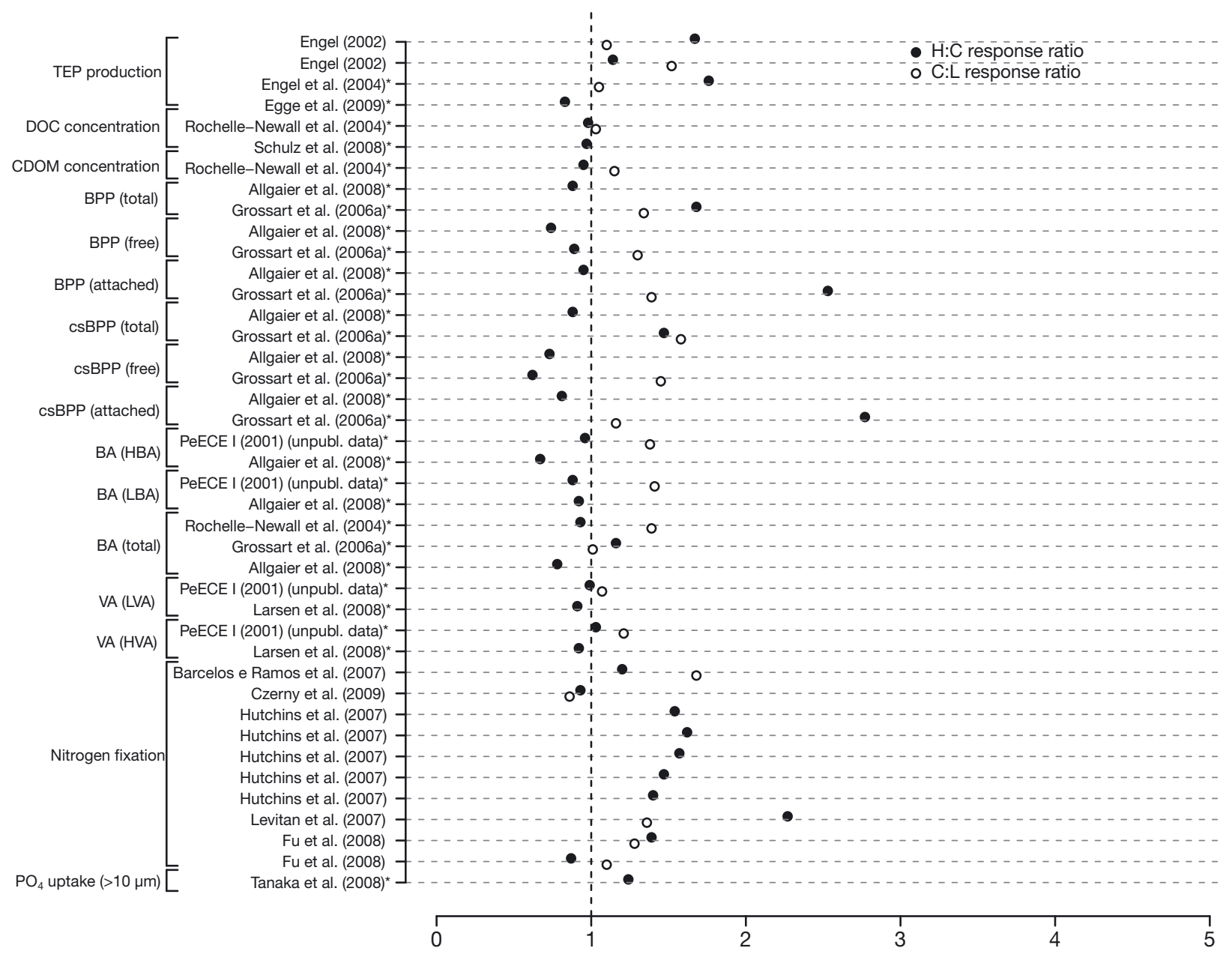

Fig. 1. Impact of ocean acidification on microbial processes and on the parameters involved. The $\mathrm{H}$ : $\mathrm{C}$ ratios, i.e. the values at high partial pressure of $\mathrm{CO}_{2}\left(\mathrm{pCO}_{2}\right)$ versus the values at control $\mathrm{pCO}_{2}$, are shown as filled circles, whereas the C:L ratios, i.e. the values at control $\mathrm{pCO}_{2}$ versus the values at low $\mathrm{pCO}_{2}$, are shown as open circles. The nitrogen fixation rate reported by Hutchins et al. (2007) at low $\mathrm{pCO}_{2}$ was 0 ; hence the $\mathrm{C}$ :L ratios could not be calculated. Asterisks $\left({ }^{*}\right)$ indicate data collected in a mesocosm experiment during which $\mathrm{pCO}_{2}$ was drifting (see 'Methods'). TEP: transparent exopolymer particles; DOC: dissolved organic carbon; CDOM: chromophoric or coloured dissolved organic matter; BPP: bacterial protein production; attached and free: Bacteria attached on particles or free; csBPP: cell-specific bacterial protein production; BA: bacterial abundance; HBA and LBA: abundances of high- and low-fluorescence Bacteria; VA: viral abundance; HVA and LVA: abundances of high- and low-fluorescence viruses; APA: alkaline phosphatase activity 


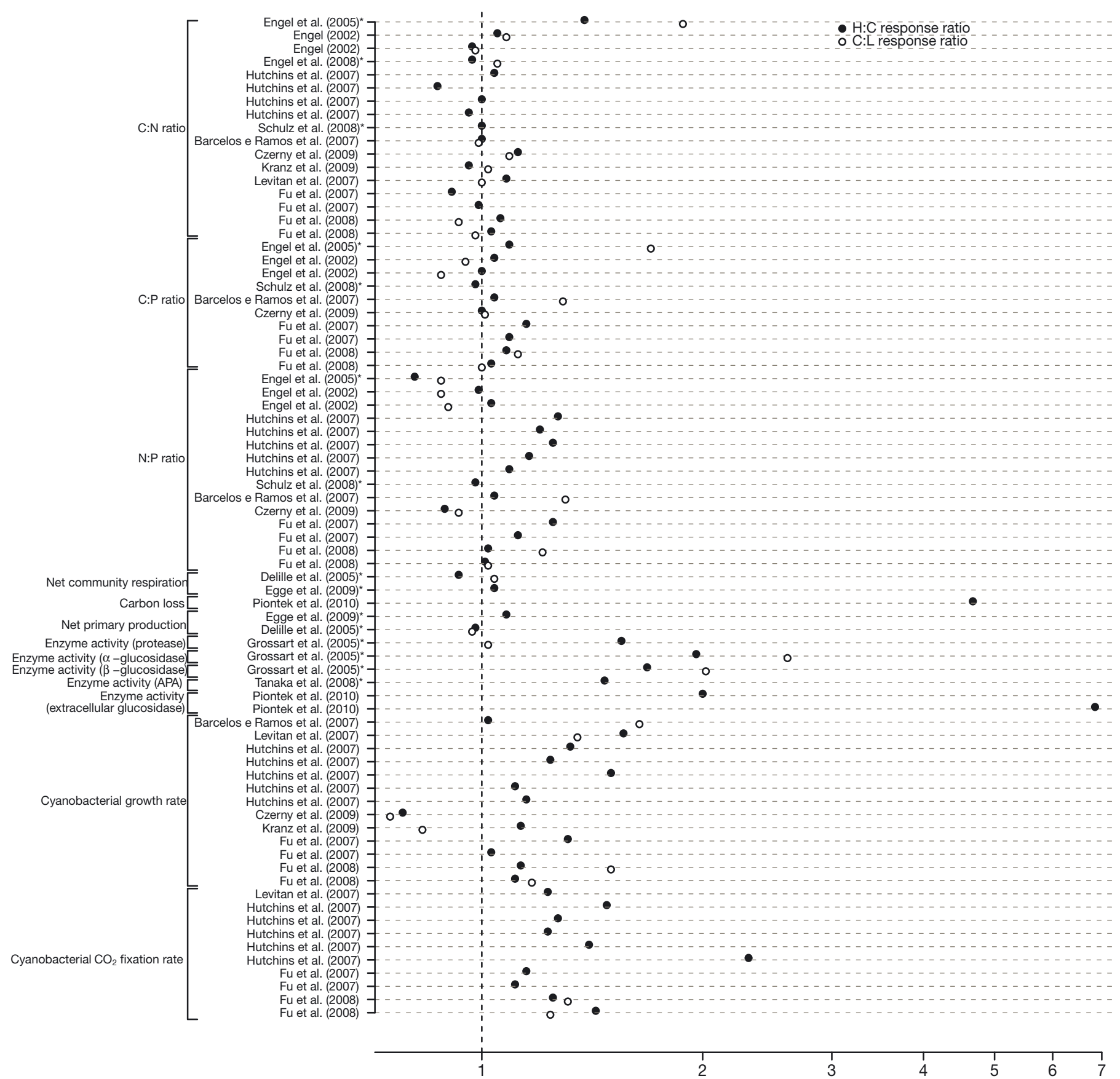

Fig. 1 (continued)

intracellular $\mathrm{pH}\left(\mathrm{pH}_{\mathrm{i}}\right)$ is maintained by a $\mathrm{pH}$ homeostatic system (Booth 1985). $\mathrm{pH}_{\mathrm{i}}$ depends on the external $\mathrm{pH}$, cytoplasmic buffers, the intracellular generation of acids and bases, and an active transport of $\mathrm{H}^{+}$(or $\left.\mathrm{OH}^{-}\right)$. On short time scales, micro-organisms are often able to buffer external changes in $\mathrm{pH}$, thereby preventing damage to internal processes and functioning. Few studies on $\mathrm{pH}$ control were performed on marine microbes, and all were carried out in experimental conditions that are not environmentally relevant (Takeuchi et al. 1997, Labare et al. 2010). Cultures were done in highly enriched media and the context of $\mathrm{CO}_{2}$ disposal, hence at $\mathrm{CO}_{2}$ and $\mathrm{pH}$ levels that are not relevant to 'natural' ocean acidification. For example, Labare et al. (2010) reported morphological changes and a temporary inhibition of growth in the marine bacterium Vibrio sp. grown at $\mathrm{pH}$ (scale not mentioned) 5.2. The recovery of growth after $6 \mathrm{~h}$ indicates 
an efficient $\mathrm{pH}$ regulation system. It is unknown how long such compensation mechanisms can withstand an environmentally relevant decline of $\mathrm{pH}$, and whether adaptation may occur over longer time scales.

\section{TEP, DOM and CDOM}

Transparent exopolymer particles (TEP) are major components of marine aggregates that are enriched in carbon relative to nitrogen or phosphorus, contribute to carbon export and provide habitats and sites for attachment of Bacteria (Passow 2002). Bacterial degradation can be an important pathway of TEP loss (Passow 2002). The effect size is above 1 (Fig. 1), suggesting a monotonous effect of elevated $\mathrm{pCO}_{2}$ that stimulates TEP production. However, the SMD of TEP production between high and control $\mathrm{pCO}_{2}$ is significantly different from 0 with the fixed effect model but it is not significantly different from 0 with the random effect model (Table 1). The SMD between the control and low $\mathrm{pCO}_{2}$ is not significant with any of the models.

Engel (2002) reported that the production of TEP by natural phytoplankton communities increases with increasing $\mathrm{pCO}_{2}$, but that at present-day $\mathrm{pCO}_{2}$, TEP production is already saturated. Higher $\mathrm{pCO}_{2}$ levels, as predicted for the future, would not lead to higher TEP production even though primary production might be stimulated (see below). In another mesocosm experiment, TEP production normalised to the abundance of Emiliania huxleyi was significantly higher in the high $\mathrm{CO}_{2}$ treatment 'future' $(\sim 710 \mu \mathrm{atm})$ than in the 'pre-

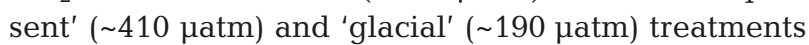
(Engel et al. 2004). This indicates a possible direct effect of $\mathrm{pCO}_{2}$ on polysaccharide exudation. However, the enhanced DIC level did not cause an increase in the particulate organic carbon (POC) concentrations, possibly due to an increased TEP production, which stimulated particle aggregation and accelerated sedimentation as previously observed by Logan et al. (1995) and Engel (2000). Mari (2008) also investigated the effect of seawater acidification on aggregation and sedimentation of TEP. Their results were similar to those of Engel et al. (2004) and suggested that a decrease of seawater $\mathrm{pH}$ would lead to a significant increase of the TEP pool. The most recent study available to date did not find a significant effect of elevated $\mathrm{pCO}_{2}$ on the TEP concentration (Egge et al. 2009). In contrast to other studies, Mari (2008) found that the buoyancy of TEP is pH-dependent, and increases in $\mathrm{pH}$ cause TEP to ascend in the water column.

Chromophoric or coloured dissolved organic matter (CDOM) is the fraction of the dissolved organic matter (DOM) that absorbs light in both the ultraviolet and visible ranges. CDOM diminishes light and is de- graded by UVA and UVB light and thus likely plays an important optical and ecological role in surface waters. There is a consensus that heterotrophic Bacteria produce CDOM (Nelson et al. 1998, Rochelle-Newall et al. 1999). However, how ocean acidification will affect heterotrophic Bacteria and CDOM release is still poorly understood. Only 1 study reported the effect of elevated $\mathrm{pCO}_{2}$ on the concentration of CDOM, preventing the use of meta-analysis. The effect size on the dissolved organic carbon (DOC) concentration is around 1 (Fig. 1) and the SMD of TEP production between high and control $\mathrm{pCO}_{2}$ is significantly different from 0 with both the fixed and random effect model (Table 1), suggesting an overall significant impact of elevated $\mathrm{pCO}_{2}$ on the DOC concentration. Too few data are available to test the significance of the SMD between the control and low $\mathrm{pCO}_{2}$.

This result contrasts with the conclusions drawn from the 2 individual studies available to date. In a mesocosm experiment carried out under different initial $\mathrm{pCO}_{2}(190,414$ and $714 \mu \mathrm{atm})$, no impact of $\mathrm{pCO}_{2}$ was observed on the concentrations of CDOM and DOC (Rochelle-Newall et al. 2004). In the same experiment, DOC was neither related to the abundance of Emiliania huxleyi nor to TEP concentration (Engel et al. 2004). No statistically significant effect of the $\mathrm{CO}_{2}$ treatment on DOC concentration was found, although during the course of the bloom, the DOC concentration increased in 2 of the 3 'future' mesocosms and in 1 of the 'present' mesocosms, but in none of the 'glacial' mesocosms (initial $\mathrm{pCO}_{2}$ of 714, 414 and $190 \mu \mathrm{atm}$, respectively). Engel et al. (2004) suggested that the different response of TEP (discussed above) and DOC may be due to differences in their bioavailability, which could have generated a rapid response of the microbial food web, possibly obscuring the effect of $\mathrm{pCO}_{2}$ on the DOC production of autotrophic cells. No statistically significant $\mathrm{CO}_{2}$ treatment effects on the concentration of DOC were detected in other PeECE experiments (Rochelle-Newall et al. 2004, Grossart et al. 2006a, Schulz et al. 2008) or in a mesocosm experiment with similar $\mathrm{CO}_{2}$ treatments (Kim et al. 2006).

\section{CARBON CYCLE}

\section{Primary production}

A relatively large number of studies have investigated the effect of elevated $\mathrm{pCO}_{2}$ on photosynthesis at the organismal level, especially to clarify the physiological and molecular mechanisms governing the carbon-concentrating mechanisms (CCMs). DIC is mostly fixed via the enzyme ribulose biphosphate carboxylase (RUBISCO), which has a relatively low affinity for $\mathrm{CO}_{2}$. 
Table 1. Summary standardised mean difference (SMD \pm SEM) for each parameter calculated using fixed-effect and randomeffect models. N: sample size; na: no data or the data do not meet the requirements for meta-analysis; p: probability. Other abbreviations as in the legend of Fig. 1

\begin{tabular}{|c|c|c|c|c|}
\hline \multirow[t]{2}{*}{ Parameters } & \multicolumn{2}{|c|}{$\begin{array}{c}\text { High vs. control } \mathrm{pCO}_{2}(\mathrm{H}: \mathrm{C}) \\
\text { SMD }\end{array}$} & \multicolumn{2}{|c|}{$\begin{array}{c}\text { Low vs. control pCO } \mathrm{pC}_{2} \text { (L:C) } \\
\text { SMD }\end{array}$} \\
\hline & Fixed effect & Random effects & Fixed effect & Random effects \\
\hline TEP production & $\begin{array}{l}0.83 \pm 0.18 \\
(p<0.001)\end{array}$ & $\begin{array}{c}1.06 \pm 1.29 \\
(p=0.41)\end{array}$ & $\begin{array}{c}-0.26 \pm 0.18 \\
(p=0.15)\end{array}$ & $\begin{array}{c}-0.26 \pm 0.18 \\
(p=0.15)\end{array}$ \\
\hline DOC concentration & $\begin{array}{c}-0.69 \pm 0.22 \\
(p=0.002)\end{array}$ & $\begin{array}{c}-0.73 \pm 0.28 \\
(p=0.009)\end{array}$ & na & na \\
\hline BPP (total) & $\begin{array}{c}-0.12 \pm 0.21 \\
(p=0.58)\end{array}$ & $\begin{array}{c}-0.13 \pm 0.78 \\
(p=0.86)\end{array}$ & na & na \\
\hline BPP (free) & $\begin{array}{c}-0.70 \pm 0.22 \\
(p=0.001)\end{array}$ & $\begin{array}{c}-0.73 \pm 0.59 \\
(p=0.21)\end{array}$ & na & na \\
\hline BPP (attached) & $\begin{array}{c}0.25 \pm 0.21 \\
(p=0.24)\end{array}$ & $\begin{array}{c}0.3 \pm 0.6 \\
(p=0.62)\end{array}$ & na & na \\
\hline csBPP (total) & $\begin{array}{c}-0.22 \pm 0.21 \\
(p=0.28)\end{array}$ & $\begin{array}{c}-0.24 \pm 0.55 \\
(p=0.66)\end{array}$ & na & na \\
\hline csBPP (free) & $\begin{array}{c}-0.82 \pm 0.21 \\
(p<0.001)\end{array}$ & $\begin{array}{c}-0.84 \pm 0.38 \\
(p=0.027)\end{array}$ & na & na \\
\hline csBPP (attached) & $\begin{array}{c}0.10 \pm 0.23 \\
(p=0.65)\end{array}$ & $\begin{array}{c}0.21 \pm 1.15 \\
(p=0.85)\end{array}$ & na & na \\
\hline BA (HBA) & $\begin{array}{c}-0.43 \pm 0.18 \\
(p=0.013)\end{array}$ & $\begin{array}{c}-1.48 \pm 1.34 \\
(p=0.27)\end{array}$ & na & na \\
\hline BA (LBA) & $\begin{array}{c}-0.63 \pm 0.17 \\
(p<0.001)\end{array}$ & $\begin{array}{l}-0.7 \pm 0.26 \\
(p=0.008)\end{array}$ & na & na \\
\hline BA (total) & $\begin{array}{l}0.06 \pm 0.1 \\
(p=0.53)\end{array}$ & $\begin{array}{c}-0.67 \pm 0.50 \\
(p=0.18)\end{array}$ & $\begin{array}{c}-0.38 \pm 0.10 \\
(p<0.001)\end{array}$ & $\begin{array}{c}-0.79 \pm 0.78 \\
(p=0.32)\end{array}$ \\
\hline VA (LVA) & $\begin{array}{c}-0.42 \pm 0.23 \\
(p=0.06)\end{array}$ & $\begin{array}{c}-1.02 \pm 1.22 \\
(p=0.406)\end{array}$ & na & na \\
\hline VA (HVA) & $\begin{array}{c}-0.61 \pm 0.22 \\
(p=0.006)\end{array}$ & $\begin{array}{c}-1.13 \pm 1.09 \\
(p=0.3)\end{array}$ & na & na \\
\hline Nitrogen fixation & $\begin{array}{l}1.06 \pm 0.26 \\
(p<0.001)\end{array}$ & $\begin{array}{l}1.95 \pm 0.68 \\
(p=0.004)\end{array}$ & $\begin{array}{c}-0.76 \pm 0.27 \\
(p=0.005)\end{array}$ & $\begin{array}{c}-0.66 \pm 0.46 \\
(p=0.15)\end{array}$ \\
\hline $\mathrm{C}: \mathrm{N}$ ratio & $\begin{array}{c}0.05 \pm 0.14 \\
(\mathrm{p}=0.72)\end{array}$ & $\begin{array}{c}-0.01 \pm 0.51 \\
(p=0.98)\end{array}$ & $\begin{array}{c}-0.84 \pm 0.15 \\
(p<0.001)\end{array}$ & $\begin{array}{c}-0.68 \pm 0.53 \\
(N=130, \mathrm{p}=0.20)\end{array}$ \\
\hline C:P ratio & $\begin{array}{c}0.26 \pm 0.17 \\
(p=0.14)\end{array}$ & $\begin{array}{c}0.27 \pm 0.26 \\
(p=0.3)\end{array}$ & $\begin{array}{c}-1.76 \pm 0.23 \\
(p<0.001)\end{array}$ & $\begin{array}{c}-1.44 \pm 0.52 \\
(p=0.005)\end{array}$ \\
\hline $\mathrm{N}: \mathrm{P}$ ratio & $\begin{array}{c}-0.48 \pm 0.19 \\
(p=0.01)\end{array}$ & $\begin{array}{c}0.69 \pm 0.59 \\
(p=0.24)\end{array}$ & $\begin{array}{c}0.49 \pm 0.27 \\
(p=0.08)\end{array}$ & $\begin{array}{c}-0.17 \pm 1.56 \\
(p=0.92)\end{array}$ \\
\hline Community respiration & $\begin{array}{c}-0.78 \pm 0.22 \\
(p=0.001)\end{array}$ & $\begin{array}{c}-0.55 \pm 0.50 \\
(p=0.28)\end{array}$ & na & na \\
\hline Net primary production & $\begin{array}{c}-0.21 \pm 0.30 \\
(p=0.48)\end{array}$ & $\begin{array}{c}0.22 \pm 0.81 \\
(p=0.78)\end{array}$ & na & na \\
\hline Cyanobacterial growth rate & $\begin{array}{c}0.68 \pm 0.21 \\
(\mathrm{~N}=69, \mathrm{p}=0.001)\end{array}$ & $\begin{array}{c}1.06 \pm 0.36 \\
(\mathrm{~N}=69, \mathrm{p}=0.003)\end{array}$ & $\begin{array}{c}-1.41 \pm 0.33 \\
(\mathrm{~N}=33, \mathrm{p}<0.001)\end{array}$ & $\begin{array}{c}-0.68 \pm 1.11 \\
(\mathrm{~N}=33, \mathrm{p}=0.54)\end{array}$ \\
\hline Cyanobacterial $\mathrm{CO}_{2}$ fixation rate & $\begin{array}{c}1.21 \pm 0.33 \\
(\mathrm{~N}=43, \mathrm{p}<0.001)\end{array}$ & $\begin{array}{c}1.58 \pm 0.49 \\
(\mathrm{~N}=43, \mathrm{p}=0.001)\end{array}$ & $\begin{array}{c}0.44 \pm 0.60 \\
(\mathrm{~N}=12, \mathrm{p}=0.46)\end{array}$ & $\begin{array}{c}-3.30 \pm 3.02 \\
(\mathrm{~N}=12, \mathrm{p}=0.27)\end{array}$ \\
\hline
\end{tabular}

In most species, RUBISCO is less than half saturated at present $\mathrm{CO}_{2}$ levels (Giordano et al. 2005). Hence, autotrophs that only rely on diffusive entry of $\mathrm{CO}_{2}$ have poor photosynthetic efficiency. However, all cyanobacteria and most algae have developed CCMs to elevate the concentration of $\mathrm{CO}_{2}$ at the site of carboxylation. It is beyond the scope of this paper to cover this literature extensively, as several excellent reviews are available (Riebesell 2004, Giordano et al. 2005,
Beardall et al. 2009). We will focus on cyanobacteria and community primary production below and simply wish to point out that large differences in the $\mathrm{CO}_{2}$ sensitivity between the major groups of eukaryotic phytoplankton exist (Riebesell 2004).

Cyanobacteria are the largest and the most widely distributed group of photosynthetic prokaryotes (Burns et al. 2005). This group has a major impact on the global carbon cycle and contributes up to $50 \%$ of the 
Table 2. Estimates of the heterogeneity of the effect size $\left(Q, H\right.$ and $I^{2}$; see 'Methods'). df: degrees of freedom; na: no data or the data do not meet the requirements for meta-analysis; p: probability; other abbreviations as in the legends to Table 1 and Fig. 1

\begin{tabular}{|c|c|c|c|c|c|c|c|c|c|c|}
\hline \multirow[t]{2}{*}{ Parameters } & \multicolumn{5}{|c|}{ - High vs. control $\mathrm{pCO}_{2}-$} & \multicolumn{5}{|c|}{ - Low vs. control $\mathrm{pCO}_{2}$} \\
\hline & $Q$ & $\mathrm{df}$ & $\mathrm{p}$ & $H$ & $I^{2}(\%)$ & $Q$ & $\mathrm{df}$ & $\mathrm{p}$ & $H$ & $I^{2}(\%)$ \\
\hline TEP production & 45.7 & 3 & $<0.001$ & 3.9 & 93 & 1.5 & 2 & 0.46 & 1 & 0 \\
\hline DOC concentration & 1.4 & 1 & $<0.001$ & 1.2 & 30 & na & na & na & na & na \\
\hline BPP (total) & 13.4 & 1 & $<0.001$ & 3.7 & 93 & na & na & na & na & na \\
\hline BPP (free) & 7.2 & 1 & 0.01 & 2.7 & 86 & na & na & na & na & na \\
\hline BPP (attached) & 7.9 & 1 & 0.01 & 2.8 & 87 & na & na & na & na & na \\
\hline csBPP (total) & 6.8 & 1 & 0.009 & 2.6 & 85 & na & na & na & na & na \\
\hline csBPP (free) & 3.1 & 1 & 0.07 & 1.8 & 68 & na & na & na & na & na \\
\hline csBPP (attached) & 26 & 1 & $<0.001$ & 5.1 & 96 & na & na & na & na & na \\
\hline BA (HBA) & 18.9 & 1 & $<0.001$ & 4.4 & 95 & na & na & na & na & na \\
\hline $\mathrm{BA}(\mathrm{LBA})$ & 1.5 & 1 & 0.22 & 1.2 & 34 & na & na & na & na & na \\
\hline BA (total) & 32.8 & 2 & $<0.001$ & 4.1 & 94 & 42.8 & 1 & $<0.001$ & 6.5 & 97 \\
\hline VA (LVA) & 22 & 1 & $<0.001$ & 4.7 & 95 & na & na & na & na & na \\
\hline VA (HVA) & 17.4 & 1 & $<0.001$ & 4.2 & 94 & na & na & na & na & na \\
\hline Nitrogen fixation & 33.72 & 9 & $<0.001$ & 1.9 & 73 & 8 & 4 & 0.09 & 1.4 & 50 \\
\hline $\mathrm{C}: \mathrm{N}$ ratio & 119.2 & 12 & $<0.001$ & 3.2 & 90 & 61.4 & 6 & $<0.001$ & 3.2 & 90 \\
\hline $\mathrm{C}: \mathrm{P}$ ratio & 11.3 & 7 & 0.13 & 1.3 & 38 & 13.5 & 4 & 0.01 & 1.8 & 71 \\
\hline $\mathrm{N}: \mathrm{P}$ ratio & 89 & 12 & $<0.001$ & 2.7 & 87 & 105.7 & 4 & $<0.001$ & 5.1 & 96 \\
\hline Community respiration & 2.1 & 1 & 0.15 & 1.5 & 53 & na & na & na & na & na \\
\hline Net primary production & 3.7 & 1 & 0.06 & 1.9 & 73 & na & na & na & na & na \\
\hline Cyanobacterial growth rate & 27.7 & 12 & 0.01 & 1.5 & 57 & 17.1 & 3 & $<0.001$ & 2.4 & 82 \\
\hline Cyanobacterial $\mathrm{CO}_{2}$ fixation rate & 13.5 & 8 & 0.09 & 1.3 & 41 & 9.4 & 2 & 0.01 & 2.2 & 79 \\
\hline
\end{tabular}

fixed carbon in marine systems (Partensky et al. 1999). Cyanobacteria are known to utilise CCMs, such as the active transport of $\mathrm{HCO}_{3}^{-}$and $\mathrm{CO}_{2}$, to facilitate $\mathrm{CO}_{2}$ fixation and maintain rapid growth at low external DIC concentrations (Badger \& Price 2003, Badger et al. 2006). It is reasonable to assume that increased $\mathrm{CO}_{2}$ availability will reduce the need for CCM activity and hence reduces the allocation of energy or nutrients for carbon acquisition (Burkhardt et al. 2001, Beardall \& Giordano 2002). This may further affect the photosynthesis, growth rate and other activities.

The effect of elevated $\mathrm{pCO}_{2}$ on the growth rate and/or photosynthesis of the widespread cyanobacterium Trichodesmium spp. was investigated by Barcelos e Ramos et al. (2007), Levitan et al. (2007), Hutchins et al. (2007) and Kranz et al. (2009). Four other cyanobacterial species were investigated: Synechococcus sp. and Prochlorococcus sp. (Fu et al. 2007), Crocosphaera watsonii (Fu et al. 2008) and Nodularia spumigena (Czerny et al. 2009).

Overall, the effect size on the growth rate is above 1 both for the $\mathrm{H}: \mathrm{C}$ and $\mathrm{C}: \mathrm{L}$ ratios (Fig. 1), suggesting a monotonous increase in growth rate as a function of increasing $\mathrm{pCO}_{2}$. One notable exception, with effect sizes below 1, is Nodularia spumigena, which exhibits a monotonous decrease in growth rate as a function of increasing $\mathrm{pCO}_{2}$. The SMD of cyanobacterial growth rate between high and control $\mathrm{pCO}_{2}$ is significantly different from 0 both with the fixed effect and random effects models (Table 1). The SMD between the control and low $\mathrm{pCO}_{2}$ is significantly different from 0 only with the fixed effect model. An additional demonstration of species specificity is the result that Synechococcus sp. exhibits a much greater response to elevated $\mathrm{pCO}_{2}$ (750 versus $380 \mu \mathrm{atm})$ and temperature $\left(4^{\circ} \mathrm{C}\right.$ increase) than Prochlorococcus sp. (Fu et al. 2007). There is some evidence that the growth rate of Crocosphaera increases at elevated $\mathrm{pCO}_{2}$ but only under Fe-replete conditions (Fu et al. 2008).

The effect size on the cyanobacterial photosynthesis (i.e. $\mathrm{CO}_{2}$ fixation rate) is above 1 both for the $\mathrm{H}: \mathrm{C}$ and $\mathrm{C}: \mathrm{L}$ ratios (Fig. 1), suggesting a monotonous increase in the rate of photosynthesis with increasing $\mathrm{pCO}_{2}$. There is only 1 exception in the study of Levitan et al. (2007), where photosynthesis was higher at low and high $\mathrm{pCO}_{2}$ than in the control. The SMD of cyanobacterial photosynthesis between high and control $\mathrm{pCO}_{2}$ was significantly different from 0 both with the fixed effect and random effects models, but the SMD between the control and low $\mathrm{pCO}_{2}$ was not significantly different from 0 (Table 1).

The stimulation of net photosynthesis at elevated $\mathrm{pCO}_{2}$ is predominantly attributed to changes in cell division (Hutchins et al. 2007, Levitan et al. 2007) but also to altered elemental ratios of carbon to nitrogen (Levitan et al. 2007, Kranz et al. 2009) or nitrogen to phosphorus (Barcelos e Ramos et al. 2007). Fu et al. (2007) reported that the photosynthetic parameters of Synechococcus sp. significantly changed at elevated $\mathrm{pCO}_{2}$ but only when combined with elevated temperature. 
There are several reports of increased community primary production of phytoplanktonic assemblages (some not microbial) at elevated $\mathrm{pCO}_{2}$. Hein \& SandJensen (1997) indicated that elevated $\mathrm{CO}_{2}$ will stimulate primary production in the North Atlantic. The PeECE mesocosm experiments also investigated the effect of elevated $\mathrm{pCO}_{2}$ on net primary production. No conspicuous change was observed in the PeECE I (Delille et al. 2005) and II (J. Egge unpubl. data) experiments, but a significant effect was found in the PeECE III experiment. Riebesell et al. (2007) reported a 27 and $39 \%$ increase in net primary production at $2 \times$ and $3 \times$ ambient $\mathrm{pCO}_{2}$, and Egge et al. (2009) found a higher cumulative primary production based on the ${ }^{14} \mathrm{C}$-incorporations at higher $\mathrm{pCO}_{2}$ towards the end of the experiment. However, other studies had reported that increased $\mathrm{pCO}_{2}$ resulted in no significant increase in primary production (Tortell et al. 2002).

\section{Bacterial abundance, production and enzyme activity}

Bacteria are the main group of organisms able to use DOC. Since they can be grazed by flagellates, some of the DOC which would otherwise be lost from the food web, can be cycled back via grazing (microbial loop; Azam et al. 1983). Inagaki et al. (2006) reported that the $\mathrm{pH}$ values of the deep-sea sediments overlying a $\mathrm{CO}_{2}$ lake ranged from 4.0 to 6.6 units, in contrast to a $\mathrm{pH}$ (presumably on the National Bureau of Standards, NBS, scale) of 7.3 outside of the $\mathrm{CO}_{2}$-hydrate zone. In their study, a strong decline in cell numbers and abundance of specific lipid biomarkers toward the liquid $\mathrm{CO}_{2}$ interface on a scale of decimetres was observed: along this gradient high abundances $\left(>10^{9} \mathrm{~cm}^{-3}\right)$ of microbial cells found in sediment pavements above the $\mathrm{CO}_{2}$ lake decreased to strikingly low cell numbers $\left(10^{7} \mathrm{~cm}^{-3}\right)$ at the liquid $\mathrm{CO}_{2} / \mathrm{CO}_{2}$-hydrate interface. In other studies performed at $\mathrm{pCO}_{2}$ levels relevant to future surface ocean acidification (190 to $1050 \mu \mathrm{atm}$ ), the total abundance of Bacteria varied considerably in phytoplankton blooms triggered in pelagic mesocosms, but $\mathrm{pCO}_{2}$ had little or no effect on bacterial abundance (BA; Rochelle-Newall et al. 2004, Grossart et al. 2006a, Allgaier et al. 2008). Note, however, that a significant impact was observed during the decline of the bloom in 1 of the experiments together with a higher growth rate and abundance of attached prokaryotes at the highest $\mathrm{pCO}_{2}$ level $(700 \mu \mathrm{atm}$; Grossart et al. 2006a). Yamada et al. (2008) also found no significant effect of $\mathrm{pCO}_{2}$ values up to $10000 \mu \mathrm{atm}$.

The H:C effect sizes of the abundance of high DNA Bacteria (HBA) and low DNA Bacteria (LBA) are lower than 1, suggesting an inhibition of bacterial abundance under high $\mathrm{pCO}_{2}$, but the $\mathrm{C}: \mathrm{L}$ ratios are higher than 1 , indicating a minimum abundance at control
$\mathrm{pCO}_{2}$ and larger abundances at low and high $\mathrm{pCO}_{2}$ (Fig. 1). Only 2 SMDs are significantly different from 0 : the high DNA Bacteria H:C ratio and the total BA L:C ratio, both with a fixed model.

Diverse responses of bacterial production (BPP) to elevated $\mathrm{pCO}_{2}$ were found, partly depending on the community considered (attached versus free Bacteria) and on the normalisation used (total BPP or cellspecific BPP, csBPP). The effect sizes suggest a monotonous response in 4 of the data sets available at low, control and high $\mathrm{pCO}_{2}$ (Fig. 1). The $\mathrm{H}: \mathrm{C}$ effect size is most often much higher than the L:C effect size. In the other 3 data sets, the response does not appear to be monotonous. Only a few SMDs of bacterial production between high and control $\mathrm{pCO}_{2}$ are significantly different from 0 with the fixed effect model (total and csBPP of free Bacteria) and the random effect model (csBPP of free Bacteria; Table 1). Too few data are available to test the significance of the SMD between the control and low $\mathrm{pCO}_{2}$.

Grossart et al. (2006a) reported that the total BPP (estimated using tritiated leucine incorporation) as well as the csBPP of total and attached Bacteria are higher at elevated $\mathrm{pCO}_{2}$. They also found a higher protease activity at elevated $\mathrm{pCO}_{2}$, whereas the activities of $\alpha$ - and $\beta$-glucosidase remained unchanged. The preferential stimulation of the abundance and activity of attached Bacteria may result from an increased production of TEP, which would provide surfaces for BaCteria and favour aggregation (Grossart et al. 2006b). Allgaier et al. (2008) suggested that there was no difference in BPP among $\mathrm{pCO}_{2}$ treatments. However, linear regressions between BPP of free-living Bacteria, BPP of attached Bacteria or csBPP of attached Bacteria and $\mathrm{C}: \mathrm{N}$ ratio of suspended matter were significantly different between $\mathrm{pCO}_{2}$ levels. Yamada et al. (2008) also reported an increase in bacterial production, but they used very high $\mathrm{pCO}_{2}$ levels ranging between 2000 and 10000 ratm.

Although there is some evidence that elevated $\mathrm{CO}_{2}$ affects some microbial processes such as bacterial production and degradation, the understanding of the mechanisms involved is still poor. Extracellular enzymes are vital for microbial metabolism, and their activity could provide clues on the mechanisms involved. Grossart et al. (2006a) found that the activity of total protease as well as $\alpha$ - and $\beta$-glucosidase was highest at elevated $\mathrm{pCO}_{2}$ levels, but this effect was statistically significant only for protease activity. Similar results were reported by Piontek et al. (2010), with higher rates of extracellular glucosidases at lower $\mathrm{pH}$. Tanaka et al. (2008) reported that the specific glucose affinity of Bacteria at $3 \mathrm{pCO}_{2}$ levels was similar.

Kranz et al. (2009) investigated the external carbonic anhydrase (eCA) activities of the cyanobacterium Tri- 
chodesmium erythraeum in response to $\mathrm{pCO}_{2}$ levels of 150,370 and $1000 \mu \mathrm{atm}$. eCA is an enzyme which promotes the conversion of $\mathrm{HCO}_{3}{ }^{-}$ions to $\mathrm{CO}_{2}$. They reported low activities of eCA, which did not change as a function of $\mathrm{pCO}_{2}$, indicating a minor role of eCA in the carbon acquisition of this species.

Among the factors which determine the consequences of bacterial DOC consumption are the rate at which biomass is produced (bacterial carbon assimilation) and the rate at which DOC is converted into $\mathrm{CO}_{2}$ (bacterial respiration). However, bacterial respiration and growth efficiency have not yet been studied with respect to ocean acidification. Also, there are no data on bacterial production rates estimated as cell division rates using incorporation of tritiated thymidine. Thus, it is not known whether $\mathrm{pCO}_{2}$ changes result in differences of the 2 main methods used for estimating bacterial production, i.e. leucine and thymidine incorporation. Such differences are known under stress situations such as UVB exposure.

\section{Organic carbon consumption and loss}

Piontek et al. (2010) recently tested the effect of ocean acidification on the degradation activity of marine Bacteria in a pH perturbation experiment. Higher loss of polysaccharides (up to $32 \%$ ) and POC were found under lowered $\mathrm{pH}$ conditions, which suggested that ocean acidification could affect the cycling of organic carbon in the future ocean by weakening the biological carbon pump and by increasing the respiratory production of $\mathrm{CO}_{2}$. Riebesell et al. (2007) reported that the community consumed up to $39 \%$ more DIC at higher $\mathrm{pCO}_{2}$, whereas nutrient uptake remained the same. This excess carbon consumption was associated with higher loss of organic carbon from the upper layer of the mesocosm. This has an implication on a variety of marine biological and biogeochemical processes. In the same mesocosm experiment, community respiration did not reveal any clear response to $\mathrm{pCO}_{2}$, neither in terms of the timing nor of the level of cumulative consumption for the $24 \mathrm{~d}$ of the experiment (Egge et al. 2009).

\section{NUTRIENT CYCLES}

Inorganic nutrients such as nitrate and phosphate are vital for microbial growth. Almost all published studies have investigated the nitrogen cycle. Tanaka et al. (2008) investigated the availability of phosphate for phytoplankton and Bacteria at $3 \mathrm{pCO}_{2}$ levels

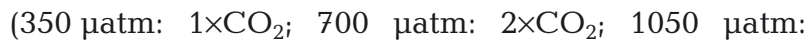
$3 \times \mathrm{CO}_{2}$ ). Its response was similar to that of the total particulate phosphorus concentration and phosphate turnover time. The phosphate transferred to the $>10 \mu \mathrm{m}$ fraction was greater in the $3 \times \mathrm{CO}_{2}$ mesocosm during the first 6 to $10 \mathrm{~d}$ when the phosphate concentration was still high. Also, the lower availability of inorganic nutrients after the phytoplankton bloom reduced the bacterial capacity to consume labile DOC. The specific alkaline phosphatase activity (APA) of Bacteria tended to be higher at $3 \times \mathrm{CO}_{2}$ than at $2 \times$ and $1 \times \mathrm{CO}_{2}$ during the phosphate depletion period.

\section{Nitrogen fixation}

Diazotrophic cyanobacteria affect marine ecosystems by providing reactive nitrogen to otherwise nitrogenlimited regions. Most effect sizes for heterocystous cyanobacteria are above 1 (Fig. 1; Barcelos e Ramos et al. 2007, Hutchins et al. 2007, Levitan et al. 2007, Fu et al. 2008, Kranz et al. 2009), whereas they are below 1 for the non-heterocystous species Nodularia spumigena (Czerny et al. 2009). The SMDs of nitrogen fixation between high and control $\mathrm{pCO}_{2}$ are significantly different from 0 with the fixed effect model and the random effect model (Table 1). The SMD between control and low $\mathrm{pCO}_{2}$ is significantly different from 0 only with the fixed effect model.

The filamentous non-heterocystous cyanobacterium Trichodesmium spp. thrives in oligotrophic areas of tropical and subtropical seas. This group contributes about half of all marine $\mathrm{N}_{2}$ fixation (Mahaffey et al. 2005). The effect of $\mathrm{pCO}_{2}$ levels ranging from 140 to $850 \mu$ atm revealed that rates of $\mathrm{N}_{2}$ fixation per unit of phosphorus utilisation more than doubled at high $\mathrm{CO}_{2}$ (Barcelos e Ramos et al. 2007). In 2 other studies, very similar results were obtained (Hutchins et al. 2007, Levitan et al. 2007). Relative to ambient or low $\mathrm{pCO}_{2}$, high $\mathrm{pCO}_{2}$ levels enhanced $\mathrm{N}_{2}$ fixation as well as the filament length and biomass of Trichodesmium (Levitan et al. 2007). For example, $\mathrm{N}_{2}$ fixation increased by $121 \%$ between 400 and 900 patm. Hutchins et al. (2007) reported a significant increase of $\mathrm{N}_{2}$ fixation and growth rate between 380 and $1500 \mu$ atm, with an increase of $63 \%$ at a $\mathrm{pCO}_{2}$ of $750 \mu \mathrm{atm}$. Kranz et al. (2009) also reported a stimulation in nitrogen fixation of $T$. erythraeum by almost $40 \%$ at a $\mathrm{pCO}_{2}$ of $1000 \mu \mathrm{atm}$ relative to $370 \mu \mathrm{atm}$. Only 1 study is available in a cyanobacterium other than Trichodesmium. The unicellular diazotroph Crocosphaera watsonii revealed $\mathrm{N}_{2}$ fixation rates that were enhanced by $40 \%$ at $750 \mu$ atm relative to that at $380 \mu$ atm (Fu et al. 2008).

It seems clear that $\mathrm{CO}_{2}$ is limiting nitrogen fixation and that ocean acidification could substantially increase, at least in short-term experiments, the fixation of $\mathrm{N}_{2}$ (and $\mathrm{CO}_{2}$ as reviewed above) of Trichodesmium. Hutchins et al. (2009) pointed out that the magnitude 
of the response of nitrogen and carbon fixation to elevated $\mathrm{pCO}_{2}$ is the largest physiological response yet reported for marine microbes. This could fundamentally alter the $\mathrm{N}$ and $\mathrm{C}$ cycles. It is important to note that the rate of $\mathrm{N}_{2}$ fixation did not continue to rise as $\mathrm{pCO}_{2}$ levels were further elevated above $750 \mu$ atm. This suggests that the observed increase of $\mathrm{N}_{2}$ fixation by Trichodesmium might level off by the end of the century (Hutchins et al. 2009).

In contrast to the non-heterocystous cyanobacteria mentioned above, the heterocystous, bloom-forming diazotroph Nodularia spumigena showed a slight decrease of $\mathrm{N}_{2}$ fixation rate at increasing $\mathrm{pCO}_{2}$ levels (Czerny et al. 2009).

\section{Nitrification}

Nitrification, another important process in the nitrogen cycle, is the biological oxidation of ammonia with oxygen into nitrite followed by the oxidation of these nitrites into nitrates. Huesemann et al. (2002) investigated the effects of $\mathrm{CO}_{2}$-induced $\mathrm{pH}$ changes on marine nitrification in the context of deep-sea $\mathrm{CO}_{2}$ disposal. They found that the rate of nitrification drops drastically with decreasing $\mathrm{pH}$. Relative to the rates at $\mathrm{pH} 8$ (presumably on the NBS scale), nitrification decreased by ca. $50 \%$ at $\mathrm{pH} 7$ and by more than $90 \%$ at $\mathrm{pH}$ 6.5, while it was completely inhibited at $\mathrm{pH} 6.0$.

\section{ELEMENTAL RATIOS}

Since the growth efficiency of heterotrophic microbes is controlled by the quality of food, any change in the elemental composition of particulate or dissolved organic matter (POM or DOM) could directly or indirectly affect processes such as growth rate, respiration and nutrient recycling (Engel et al. 2005). The effect sizes on the C:N ratio are distributed around 1 for all studies but 1 (Fig. 1). Nevertheless, the SMD is significantly different from 0 with the fixed effect model between the high and control $\mathrm{pCO}_{2}$ and between the control and low $\mathrm{pCO}_{2}$ (Table 1). The effect sizes on the $\mathrm{C}: \mathrm{P}$ ratio do not seem to follow a consistent pattern (Fig. 1). The SMD between the high and control $\mathrm{pCO}_{2}$ is not significantly different from 0 with both the fixed and random effect models but is statistically different from 0 between the control and low $\mathrm{pCO}_{2}$ (Table 1). Finally, the effect size of the N:P ratio also does not seem to follow a coherent pattern in the 5 studies available to date (Fig. 1), but the SMD is nevertheless statistically significant with the fixed effect model between the high and control $\mathrm{pCO}_{2}$ and between the control and low $\mathrm{pCO}_{2}$ (Table 1).
Significant changes in the consumption ratio of various inorganic nutrients in response to increasing $\mathrm{pCO}_{2}$ were reported by Tortell et al. (2002). They reported that a pelagic community of the Equatorial Pacific consumed $\mathrm{NO}_{3}{ }^{-}$and $\mathrm{H}_{2} \mathrm{SiO}_{3}$ in a ratio close to $1: 1$ (range from 1.0 to 1.55$)$ in the high $\mathrm{CO}_{2}(750 \mu \mathrm{atm})$ treatment, while the consumption ratio was much higher (2.16 to 2.71) at a low $\mathrm{pCO}_{2}$ of 150 patm. In contrast, the assimilation of nitrate and phosphate was similar in the $3 \mathrm{CO}_{2}$ treatments investigated by Engel et al. (2005) in a mesocosm experiment. The concentration of particulate constituents was highly variable among the replicate mesocosms, likely disguising direct $\mathrm{CO}_{2}$ related effects.

Changes in the C:N:P ratios have been shown in cultures of several eukaryotic phytoplankton groups (Riebesell 2004). Differential effects were observed on the 2 main cyanobacterial groups: Synechococcus and Prochlorococcus. Fu et al. (2007) reported that Synechococcus sp. had a slight decrease in C:N and an increase in $\mathrm{C}: \mathrm{P}$ and $\mathrm{N}: \mathrm{P}$ at the higher $\mathrm{CO}_{2}$ concentration, while there was no significant difference in Prochlorococcus sp. As mentioned in the previous section, $\mathrm{pCO}_{2}$ has an effect on the $\mathrm{N}_{2}$ uptake and $\mathrm{C}$ fixation rates of some nitrogen-fixing cyanobacteria. This could significantly affect the $\mathrm{C}: \mathrm{N}$ and $\mathrm{N}: \mathrm{P}$ ratios, but the effect found in the various experiments is not consistent. Elevated $\mathrm{pCO}_{2}$ increased the $\mathrm{C}: \mathrm{N}$ ratio in 3 studies (Levitan et al. 2007, Czerny et al. 2009, Kranz et al. 2009) but had no effect in another study (Barcelos e Ramos et al. 2007). The N:P ratio of Trichodesmium sp. increases at elevated $\mathrm{pCO}_{2}$ (Barcelos e Ramos et al. 2007), whereas the N:P ratio of Nodularia spumigena decreases (Czerny et al. 2009).

Changes in elemental ratios were also reported at the community level and could have a considerable impact on the strength of the biological pump. For example, in a mesocosm experiment, Riebesell et al. (2007) found that the stoichiometry of C:N drawdown increased from 6 at low $\mathrm{CO}_{2}$ to 8 at high $\mathrm{CO}_{2}$, thus exceeding the Redfield C:N ratio of 6.6 in today's ocean. These authors speculated that this could translate to an excess $\mathrm{CO}_{2}$ sequestration potential, through the biological carbon pump, of $116 \mathrm{Pg} \mathrm{C}$ until 2100. Increasing $\mathrm{C}: \mathrm{N}$ ratios would also lower the nutritional value of primary-produced organic matter, which may affect the efficiency of bacterial degradation and zooplankton reproduction. In the same mesocosm experiment, Bellerby et al. (2008) also found that the cumulative $\mathrm{C}: \mathrm{N}$ and $\mathrm{C}: \mathrm{P}$ ratios of organic production until the height of the bloom decreased with increasingpCO $\mathrm{CO}_{2}$. The $\mathrm{C}: \mathrm{N}: \mathrm{P}$ ratios were 1:6.3:121 at 350 atm,

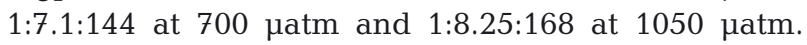
Other studies also reported species-dependent changes of phytoplankton $\mathrm{C}: \mathrm{N}: \mathrm{P}$ ratios at elevated 
$\mathrm{pCO}_{2}$ (Burkhardt \& Riebesell 1997, Burkhardt et al. 1999, Tortell et al. 2000).

\section{MORTALITY}

Viral lysis and grazing are the 2 main factors of microbial mortality. Lysis transfers lysis products such as the cell content (including viruses) and cell debris into the DOM pool. This viral shunt (Wilhelm \& Suttle 1999) increases bacterial production and respiration and enhances nutrient recycling. As mentioned above, grazing on Bacteria transfers organic matter back to the food web, whereas grazing on phytoplankton is the first step in the grazing food chain, which also plays a key role in carbon cycling. Thus, the relative contribution of viral lysis and grazing is an important factor for shaping the fate of primary production and bacterial production. Not much is known about how changes in $\mathrm{pCO}_{2}$ could influence mortality.

Rochelle-Newall et al. (2004) reported that elevated $\mathrm{pCO}_{2}$ had no effect on total viral abundance (VA), thus suggesting that viral lysis was not influenced strongly. Viral lysis rates have not yet been measured in combination with $\mathrm{pCO}_{2}$ changes. For grazing, more information is available. Riebesell et al. (2007) noted that the DIC consumption increased with increasing $\mathrm{pCO}_{2}$, whereas the nutrient uptake remained stable. This leads to an offset in the Redfield ratios, and possibly causes a deterioration of the food quality. Veloza et al. (2006) reported that some microzooplankton groups, e.g. some dinoflagellates, may have the capacity to use low quality prey. However, it is still unclear how and to what extent this takes place. Until now, only 2 studies investigated the response of microzooplankton grazing to increasing $\mathrm{pCO}_{2}$ levels. In the PeECE III experiment, grazing was highly dynamic over time, and no effect of $\mathrm{CO}_{2}$ on microzooplankton grazing was found (Suffrian et al. 2008). Rose et al. (2009) investigated the potential effects of climate change variables (temperature and $\mathrm{pCO}_{2}$ ) on the trophic dynamics using a shipboard continuous culture system. They observed increases in both the abundance and grazing rates of microzooplankton in the high $\mathrm{pCO}_{2}$ treatments $(690 \mu \mathrm{atm})$ relative to ambient $\mathrm{pCO}_{2}$ treatments (390 $\left.\mu \mathrm{atm}\right)$.

\section{COMMUNITY COMPOSITION AND DIVERSITY}

Changes in community composition in the sense of differences in the relative abundance of large plankton groups have been documented for $\mathrm{pCO}_{2}$ manipulation experiments and are basically the result of differences in the time developments of different groups. Changes in diversity are considered in the following as changes of the species composition.

\section{Phytoplankton}

Phytoplanktonic diversity was profoundly affected by elevated $\mathrm{pCO}_{2}$ in some but not all perturbation experiments performed at the community level (Allgaier et al. 2008, Paulino et al. 2008). Changes in phytoplankton diversity also led to changes in bacterial community structure and subsequently in bacterial activities.

Tortell et al. (2002) provided direct evidence that $\mathrm{CO}_{2}$ concentrations can influence the species composition of a marine phytoplankton assemblage. The phytoplankton assemblage exposed to $\mathrm{pCO}_{2}$ levels of 150 and 750 uatm was dominated by diatoms and Phaeocystis sp. by the end of the experiment, but the abundance of diatoms decreased by $\sim 50 \%$ at low $\mathrm{pCO}_{2}$ relative to high $\mathrm{pCO}_{2}$ levels, while the abundance of Phaeocystis increased by about $60 \%$. This shift associated with a higher ratio of nitrate:silicate $(\mathrm{N}: \mathrm{Si})$ and $\mathrm{N}: \mathrm{P}$ consumption at low $\mathrm{pCO}_{2}$ also suggested that $\mathrm{CO}_{2}$ concentrations could potentially influence competition among marine phytoplankton taxa and affect oceanic nutrient cycling.

\section{Prokaryotes}

Mühling et al. (2006) did not find any changes in the diversity of Bacteria subject to different $\mathrm{pCO}_{2}$ levels in a $\mathrm{CO}_{2}$ perturbation experiment carried out in mesocosms. Vega Thurber et al. (2009) reported changes in the diversity of coral-associated microbiota, which shifts from a healthy-associated community to a community often found on diseased corals (e.g. Bacterioidetes, Fusobacteria and Fungi) after a strong decline in $\mathrm{pH}$ (8.1 to 6.7). Additionally, decreased $\mathrm{pH}$ as well as other stressors, such as elevated temperature, nutrients and DOC, led to an increased abundance of genes involved in virulence, stress resistance and production of secondary metabolites.

The diversity of free-living Bacteria of pelagic mesocosms assessed by community fingerprinting changes with $\mathrm{pCO}_{2}$, whereas that of attached Bacteria seems to be independent of $\mathrm{pCO}_{2}$ and coupled to the development of the phytoplankton bloom (Allgaier et al. 2008).

\section{Viruses and grazers}

Larsen et al. (2008) investigated how the virioplankton community responded to increased levels of $\mathrm{CO}_{2}$ during the PeECE III mesocosm experiment. Some 
viral populations detected and enumerated by flow cytometry did not respond to altered $\mathrm{CO}_{2}$ levels. No clear effect was found in the 'low-fluorescence viruses' (LFV), 'medium-fluorescence viruses' (MFV) and 'putative large viruses' (PLV). However, the 'highfluorescence viruses' (HFV) exhibited a higher maximum abundance in the $1 \times \mathrm{CO}_{2}$ than in the $2 \times$ and $3 \times \mathrm{CO}_{2}$ mesocosms, thus suggesting changes in viral diversity. The abundance of Emiliania huxleyi virus (EhV) and an unidentified double-stranded DNA (dsDNA) virus decreased with increasing $\mathrm{CO}_{2}$ levels. Only 1 study investigated the effect of elevated $\mathrm{pCO}_{2}$ on the community composition of viruses (Larsen et al. 2008). In their study, 2 specific large dsDNA viruses (EhV and $\mathrm{CeV}$, infecting the haptophytes E. huxleyi and Crysochromulina ericina) were identified. Their results indicate that the change in parameters of the carbonate chemistry might affect the marine pelagic food web at the viral diversity level. It also demonstrated that in order to unravel ecological problems as to how $\mathrm{pCO}_{2}$ and nutrients affect the relationship between marine algal viruses and their hosts, an effort to develop molecular markers used to identify both hosts and viruses is needed. Nothing is known about the effect of $\mathrm{pCO}_{2}$ on the diversity of grazers.

\section{DISCUSSION AND CONCLUSIONS}

Microbial processes play an important role in the functioning and the biogeochemical cycles of marine ecosystems. Although some obvious effects of ocean acidification on microbes were detected, their response is not always consistent and our understanding remains poor. There are many gaps and challenges for future research.

Most data on the effect of ocean acidification on microbial processes and diversity were gathered in perturbation experiments carried out in the laboratory and in mesocosms. Few studies investigated the simultaneous effects of ocean acidification and other perturbations. Yet, it is well established that microbial processes are greatly affected by changes in temperature and light, as well as changes in the supply of inorganic nutrients and organic matter (e.g. Kirchman et al. 2009). It is therefore critical that the interactions between the carbonate chemistry and other parameters are investigated. Equally critical is the need to use $\mathrm{pCO}_{2}$ gradients rather than only $2 \mathrm{pCO}_{2}$ levels to determine critical threshold levels for parameterising biogeochemical models. Open water $\mathrm{CO}_{2}$ fertilisation experiments still seem unrealistic (Lance 2009), but it is potentially rewarding to take advantage of systems naturally enriched with $\mathrm{CO}_{2}$ such as shallow-water $\mathrm{CO}_{2}$ vents (Hall-Spencer et al. 2008), deep-sea vents
(Inagaki et al. 2006), cold-eddies and upwelling systems (Feely et al. 2008), which have lower pH and high $\mathrm{pCO}_{2}$ levels compared to ambient water and are thus highly suitable to study effects of ocean acidification, although the data interpretation is challenging due to factors such as advection or migrations.

There is evidence for acclimation to the $\mathrm{pH}_{\mathrm{i}}$ regulation by a Vibrio strain (Labare et al. 2010). Adaptation, i.e. adjustment to environmental change by genetic change, is likely faster in microbes than in multi-cellular marine organisms. This is due to their short generation time of a few days, which allows for thousands of generations by 2100, hence increasing the accumulation of mutations, and, at least for prokaryotes, due to more efficient lateral gene transfer. Most experiments have been conducted over short periods (days to weeks), and there is a strong need to carry out longerterm experiments to detect if adaptation or acclimation occurs. Genomics, transcriptomics, proteomics and assessment of the expression of specific marker genes for crucial functions are among the most promising methods that are or soon will be available to tackle these problems.

So far, most studies have investigated individual species. More research is needed at multi-species and community scales. Losses of diversity in the sense of extinction of species are unlikely for free-living microorganisms. However, a large body of research supports the idea that free-living microbial taxa exhibit biogeographic patterns (Martiny et al. 2006). Recently, the socalled 'rare biosphere' was detected, i.e. bacterial phylotypes which only occur in low abundance (Sogin et al. 2006) and may serve as seed banks available for adaptation to environmental changes (such as increasing $\mathrm{pCO}_{2}$ ) at the species level. Such questions can be addressed by large-scale sequence approaches such as high-throughput DNA sequencing. The decrease in costs is making this approach affordable.

Until now, no standard protocols have been available to manipulate the carbonate chemistry during perturbation experiments and no guidelines have been available for data reporting. Consequently, some of the experiments published to date are difficult to interpret, for example due to inadequate $\mathrm{pCO}_{2}$ levels or the lack of information in the data reporting, which seriously hampers comparative studies and meta-analyses. The publication of the 'Guide for best practices on ocean acidification research and data reporting' (Riebesell et al. 2010) will hopefully lead to better experimental set ups and reporting in future publications.

Joint et al. (in press) pointed out that ocean $\mathrm{pH}$ is variable on short time scales in surface waters and also as a function of depth. They noted that microbial processes continue at depths where $\mathrm{pH}$ reaches values projected in the surface ocean in 2100, asked whether 
'microbial assemblages will continue to function at the lower $\mathrm{pH}$ values that are projected for the near future', and suggested a null hypothesis that biogeochemical processes other than calcification will not be fundamentally different in a high- $\mathrm{CO}_{2}$ ocean. Meta-analysis is the right tool to test the null hypothesis that ocean acidification will have no effect on microbial processes. Although it has not proven to be of great use for many variables because of the low sample sizes, notable exceptions are nitrogen fixation, cyanobacterial photosynthesis and, to a lesser extent, elemental ratios. This review and analysis therefore suggests that it is unlikely that any microbial process will cease to function due to ocean acidification and that the null hypothesis of Joint et al. (in press) can be rejected. The rates of several processes will be affected by ocean acidification, some positively, others negatively.

Another outcome of our meta-analysis is that the response of almost all parameters to ocean acidification is heterogenous among studies, suggesting the occurrence of confounding effects. There is no doubt that the launch of major national and international projects on ocean acidification will considerably increase the number of datasets available over the next few years and will lead to more solid conclusions on the effect of ocean acidification on microbial processes.

Acknowledgements. The organisers of the 11th Symposium on Aquatic Microbial Ecology held in Piran, Slovenia, in 2009 kindly invited us to participate. Thanks to A. M. Nisumaa for invaluable help with data compilation and production of Fig. 1. This work is a contribution to the European Project on Ocean Acidification (EPOCA), which received funding from the European Community's Seventh Framework Programme (FP7/2007-2013) under grant agreement no. 211384, the ANR projects AQUAPHAGE and MAORY of the French Research Ministry and the FR-EPOCA project of the Institut Polaire Français Paul Émile Victor (IPEV).

\section{LITERATURE CITED}

Allgaier M, Riebesell U, Grossart HP (2008) Coupling of heterotrophic bacteria to phytoplankton bloom development at different $\mathrm{pCO}_{2}$ levels: a mesocosm study. Biogeosciences 5:1007-1022

Azam F, Fenchel T, Field JG, Gray JS, Meyer Reil LA, Thingstad F (1983) The ecological role of water-column microbes in the sea. Mar Ecol Prog Ser 10:257-263

Badger MR, Price GD (2003) $\mathrm{CO}_{2}$ concentrating mechanisms in cyanobacteria: molecular components, their diversity and evolution. J Exp Bot 54:609-622

Badger MR, Price GD, Long BM, Woodger FJ (2006) The environmental plasticity and ecological genomics of the cyanobacterial $\mathrm{CO}_{2}$ concentrating mechanism. J Exp Bot 57:249-265

Barcelos e Ramos J, Biswas H, Schulz KG, LaRoche J, Riebesell U (2007) Effect of rising atmospheric carbon dioxide on the marine nitrogen fixer Trichodesmium. Glob Biogeochem Cycles 21:GB2028 doi:2010.1029/2006GB002898
Beardall J, Giordano M (2002) Ecological implications of microalgal and cyanobacterial CCMs and their regulation. Funct Plant Biol 29:335-347

Beardall J, Stojkovic S, Larsen S (2009) Living in a high $\mathrm{CO}_{2}$ world: impacts of global climate change on marine phytoplankton. Plant Ecol Divers 2:191-205

Bellerby RGJ, Schulz KG, Riebesell U, Neill C and others (2008) Marine ecosystem community carbon and nutrient uptake stoichiometry under varying ocean acidification during the PeECE III experiment. Biogeosciences 5: $1517-1527$

> Booth IR (1985) Regulation of cytoplasmic pH in bacteria. Microbiol Rev 49:359-378

Borenstein M, Hedges LV, Higgins JPT, Rothstein HR (2009) Introduction to meta-analysis. John Wiley \& Sons, Chichester

Burkhardt S, Riebesell U (1997) $\mathrm{CO}_{2}$ availability affects elemental composition (C:N:P) of the marine diatom Skeletonema costatum. Mar Ecol Prog Ser 155:67-76

Burkhardt S, Riebesell U, Zondervan I (1999) Effects of growth rate, $\mathrm{CO}_{2}$ concentration, and cell size on the stable carbon isotope fractions in marine phytoplankton. Geochim Cosmochim Acta 63:3729-3741

Burkhardt S, Amoroso G, Riebesell U, Sültemeyer D (2001) $\mathrm{CO}_{2}$ and $\mathrm{HCO}_{3}{ }^{-}$uptake in marine diatoms acclimated to different $\mathrm{CO}_{2}$ concentrations. Limnol Oceanogr 46: 1378-1391

Burns R, MacDonald CD, McGinn PJ, Campbell DA (2005) Inorganic carbon repletion disrupts photosynthetic acclimation to low temperature in the cyanobacterium Synechococcus elongatus. J Phycol 41:322-334

Caldeira K, Wickett ME (2003) Anthropogenic carbon and ocean $\mathrm{pH}$. Nature 425:365

> Cavicchioli R (2002) Extremophiles and the search for extraterrestrial life. Astrobiology 2:281-292

> Czerny J, Barcelos e Ramos J, Riebesell U (2009) Influence of elevated $\mathrm{CO}_{2}$ concentrations on cell division and nitrogen fixation rates in the bloom-forming cyanobacterium Nodularia spumigena. Biogeosciences 6:1865-1875

> Delille B, Harley J, Zondervan I, Jacquet S and others (2005) Response of primary production and calcification to changes of $\mathrm{pCO}_{2}$ during experimental blooms of the coccolithophorid Emiliania huxleyi. Glob Biogeochem Cycles 19:GB2023 doi:10.1029/2004GB002318

Dickson A (2010) The carbon dioxide system in seawater: equilibrium chemistry and measurements. In: Riebesell U, Fabry VJ, Hansson L, Gattuso JP (eds), Guide to best practices for ocean acidification research and data reporting. Publications Office of the European Union, Luxembourg, p 17-40

Dupont S, Dorey N, Thorndyke M (2010) What meta-analysis can tell us about vulnerability of marine biodiversity to ocean acidification? Estuar Coast Shelf Sci 89:182-185

Egge JK, Thingstad TF, Larsen A, Engel A, Wohlers J, Bellerby RGJ, Riebesell U (2009) Primary production during nutrient-induced blooms at elevated $\mathrm{CO}_{2}$ concentrations. Biogeosciences 6:877-885

Engel A (2000) The role of transparent exopolymer particles (TEP) in the increase in apparent particles stickiness $(\alpha)$ during the decline of a diatom bloom. J Plankton Res 22:485-497

Engel A (2002) Direct relationship between $\mathrm{CO}_{2}$ uptake and transparent exopolymer particle production in natural phytoplankton. J Plankton Res 24:49-53

Engel A, Delille B, Jacquet S, Riebesse U, Rochelle-Newall E, Terbrüggen A, Zondervan I (2004) Transparent exopolymer particles and dissolved organic carbon production by 
Emiliania huxleyi exposed to different $\mathrm{CO}_{2}$ concentrations: a mesocosm experiment. Aquat Microb Ecol 34: 93-104

Engel A, Zondervan I, Aerts K, Beaufort L and others (2005) Testing the direct effect of $\mathrm{CO}_{2}$ concentration on a bloom of the coccolithophorid Emiliania huxleyi in mesocosm experiments. Limnol Oceanogr 50:493-507

Engel A, Schulz K, Riebesell U, Bellerby RGJ, Delille B, Schartau M (2008) Effects of $\mathrm{CO}_{2}$ on particle size distribution and phytoplankton abundance during a mesocosm bloom experiment (PeECEII). Biogeosciences 5:509-521

Feely RA, Sabine CL, Hernandez-Ayon JM, Ianson D, Hales B (2008) Evidence for upwelling of corrosive 'acidified' water onto the continental shelf. Science 320:1490-1492

Fu FX, Warner ME, Zhang Y, Feng Y, Hutchins DA (2007) Effects of increased temperature and $\mathrm{CO}_{2}$ on photosynthesis, growth, and elemental ratios in marine Synechococcus and Prochlorococcus (Cyanobacteria). J Phycol 43: 485-496

Fu FX, Mulholland MR, Garcia NS, Beck A and others (2008) Interactions between changing $\mathrm{pCO}_{2}, \mathrm{~N}_{2}$ fixation, and Fe limitation in the marine unicellular cyanobacterium Crocosphaera. Limnol Oceanogr 53:2472-2484

Gates S (2002) Review of methodology of quantitative reviews using meta-analysis in ecology. J Anim Ecol 71:547-557

Gattuso JP, Lavigne H (2009) Technical note: approaches and software tools to investigate the impact of ocean acidification. Biogeosciences 6:2121-2133

Giordano M, Beardall J, Raven JA (2005) $\mathrm{CO}_{2}$ concentrating mechanisms in algae: mechanisms, environmental modulation, and evolution. Annu Rev Plant Biol 56:99-131

> Grossart HP, Allgaier M, Passow U, Riebesell U (2006a) Testing the effect of $\mathrm{CO}_{2}$ concentration on dynamics of marine heterotrophic bacterioplankton. Limnol Oceanogr 51:1-11

Grossart HP, Czub G, Simon M (2006b) Algae-bacteria interactions and their effects on aggregation and organic matter flux in the sea. Environ Microbiol 8:1074-1084

Hall-Spencer JM, Rodolfo-Metalpa R, Martin S, Ransome E and others (2008) Volcanic carbon dioxide vents show ecosystem effects of ocean acidification. Nature 454:96-99

- Hein M, Sand-Jensen K (1997) $\mathrm{CO}_{2}$ increases oceanic primary production. Nature 388:526-527

> Hendriks IE, Duarte CM, Alvarez M (2010) Vulnerability of marine biodiversity to ocean acidification: a meta-analysis. Estuar Coast Shelf Sci 86:157-164

Huesemann MH, Skillman AD, Crecelius EA (2002) The inhibition of marine nitrification by ocean disposal of carbon dioxide. Mar Pollut Bull 44:142-148

Hutchins DA, Fu FX, Zhang Y, Warner ME and others (2007) $\mathrm{CO}_{2}$ control of Trichodesmium $\mathrm{N}_{2}$ fixation, photosynthesis, growth rates, and elemental ratios: implications for past, present, and future ocean biogeochemistry. Limnol Oceanogr 52: 1293-1304

Hutchins DA, Mulholland MR, Fu FX (2009) Nutrient cycles and marine microbes in a $\mathrm{CO}_{2}$-enriched ocean. Oceanography 22:128-145

- Inagaki F, Kuypers MMM, Tsunogai U, Ishibashi JI and others (2006) Microbial community in a sediment-hosted $\mathrm{CO}_{2}$ lake of the southern Okinawa Trough hydrothermal system. Proc Natl Acad Sci USA 103:14164-14169

Joint I, Doney SC, Karl DM (in press) Will ocean acidification affect marine microbes? ISME J, doi:10.1038/ismej. 2010.79

Kim JM, Lee K, Shin K, Kang JH and others (2006) The effect of seawater $\mathrm{CO}_{2}$ concentration on growth of natural phytoplankton assemblage in a controlled mesocosm experiment. Limnol Oceanogr 51: 1629-1636
Kirchman DL (2008) Microbial ecology of the oceans, 2nd edn. John Wiley \& Sons, Hoboken, NJ

Kirchman DL, Moran XA, Ducklow H (2009) Microbial growth in the polar oceans - role of temperature and potential impact of climate change. Nat Rev Microbiol 7: 451-459

Kranz SA, Sültemeyer D, Richter KU, Rost B (2009) Carbon acquisition by Trichodesmium: the effect of $\mathrm{pCO}_{2}$ and diurnal changes. Limnol Oceanogr 54:548-559

Labare MP, Bays JT, Butkus MA, Snyder-Leiby T and others (2010) The effects of elevated carbon dioxide levels on a Vibrio sp. isolated from the deep-sea. Environ Sci Pollut Res Int 17:1009-1015

Lance V (2009) Carbon productivity responses to increased dissolved inorganic carbon concentrations in surface ocean: exploring the feasibility of an in situ carbon addition experiment. Workshop report. LDEO in situ $\mathrm{CO}_{2}$ Workshop, 2324 March 2009, Lamont-Doherty Earth Observatory, New York, NY. Available at www.ldeo.columbia.edu/ vlance/ CO2WorkshopReportonWEB_16Jun09.pdf

- Larsen JB, Larsen A, Thyrhaug R, Bratbak G, Sandaa RA (2008) Response of marine viral populations to a nutrient induced phytoplankton bloom at different $\mathrm{pCO}_{2}$ levels. Biogeosciences 5:523-533

Lavigne H, Gattuso JP (2010) seacarb: seawater carbonate chemistry with R. R package version 2.3.3. Available at: http://CRAN.R-project.org/package=seacarb

Levitan O, Rosenberg G, Setlik I, Setlikova E and others (2007) Elevated $\mathrm{CO}_{2}$ enhances nitrogen fixation and growth in the marine cyanobacterium Trichodesmium. Glob Change Biol 13: 531-538

> Logan BE, Passow U, Alldredge AL, Grossart HP, Simon M (1995) Rapid formation and sedimentation of large aggregates is predictable from coagulation rates (half-lives) of transparent exopolymer particles (TEP). Deep-Sea Res II 42:203-214

- Mahaffey C, Michaels AF, Capone DG (2005) The conundrum of marine $\mathrm{N}_{2}$ fixation. Am J Sci 305:546-595

> Mari X (2008) Does ocean acidification induce an upward flux of marine aggregates? Biogeosciences 5:1023-1031

> Martiny JBH, Bohannan BJM, Brown JH, Colwell RK and others (2006) Microbial biogeography: putting microorganisms on the map. Nat Rev Microbiol 4:102-112

Mühling M, Fuller NJ, Somerfield PJ, Post AF and others (2006) High resolution genetic diversity studies of marine Synechococcus isolates using rpoC1-based restriction fragment length polymorphism. Aquat Microb Ecol 45: 263-275

> Nelson NB, Seigel DA, Michaels AF (1998) Seasonal dynamics of colored dissolved organic matter in the Sargasso Sea. Deep-Sea Res I 45:931-957

Nisumaa AM, Pesant S, Bellerby RGJ, Middelburg JJ and others (2010) EPOCA/EUR-OCEANS data compilation on the biological and biogeochemical responses to ocean acidification. Earth Syst Sci Data 2:167-175

> Orr JC, Fabry VJ, Aumont O, Bopp L and others (2005) Anthropogenic ocean acidification over the twenty-first century and its impact on calcifying organisms. Nature 437:681-686

> Partensky F, Hess WR, Vaulot D (1999) Prochlorococcus, a marine photosynthetic prokaryote of global significance. Microbiol Mol Biol Rev 63:106-127

> Passow U (2002) Transparent exopolymer particles (TEP) in aquatic environments. Prog Oceanogr 55:287-333

- Paulino AI, Egge JK, Larsen A (2008) Effects of increased atmospheric $\mathrm{CO}_{2}$ on small and intermediate sized osmotrophs during a nutrient induced phytoplankton bloom. Biogeosciences 5:739-748 
Piontek J, Lunau M, Händel N, Borchard G, Wurst M, Engel A (2010) Acidification increases microbial polysaccharide degradation in the ocean. Biogeosciences 7:1615-1624

Riebesell U (2004) Effects of $\mathrm{CO}_{2}$ enrichment on marine phytoplankton. J Oceanogr 60:719-729

Riebesell U, Schulz KG, Bellerby RGJ, Botros M and others (2007) Enhanced biological carbon consumption in a high $\mathrm{CO}_{2}$ ocean. Nature 450:545-548

Riebesell U, Bellerby RGJ, Grossart HP, Thingstad F (2008) Mesocosm $\mathrm{CO}_{2}$ perturbation studies: from organism to community level. Biogeosciences 5:1157-1164

Riebesell U, Fabry V, Hansson L, Gattuso JP (2010) Guide to best practices for ocean acidification research and data reporting. Publications Office of the European Union, Luxembourg

Rochelle-Newall EJ, Fisher TR, Fan CL, Glibert PM (1999) Dynamics of chromophoric dissolved organic matter and dissolved organic carbon in experimental mesocosms. Int J Remote Sens 20:627-641

Rochelle-Newall E, Delille B, Frankignoulle M, Gattuso JP and others (2004) Chromophoric dissolved organic matter in experimental mesocosms maintained under different $\mathrm{pCO}_{2}$ levels. Mar Ecol Prog Ser 272:25-31

Rose JM, Feng YY, Gobler CJ, Gutierrez R, Hare CE, Leblanc $\mathrm{K}$, Hutchins DA (2009) Effects of increased $\mathrm{pCO}_{2}$ and temperature on the North Atlantic spring bloom. II. Microzooplankton abundance and grazing. Mar Ecol Prog Ser 388:27-40

Sabine CL, Feely RA, Gruber N, Key RM and others (2004) The oceanic sink for anthropogenic $\mathrm{CO}_{2}$. Science 305: 367-371

Santana-Casiano JM, González-Dávila M, Rueda MJ, Llinás O, González-Dávila EF (2007) The interannual variability of oceanic $\mathrm{CO}_{2}$ parameters in the northeast Atlantic subtropical gyre at the ESTOC site. Glob Biogeochem Cycles 21:GB1015 doi:10.1029/2006GB002788

Schulz KG, Riebesell U, Bellerby RGJ, Biswas H and others (2008) Build-up and decline of organic matter during PeECE III. Biogeosciences 5:707-718

Schwarzer G (2010) meta: meta-analysis with R. R package version 1.1-8. Available at: http://CRAN.R-project.org/ package $=$ meta

Sogin ML, Morrison HG, Huber JA (2006) Microbial diversity in the deep sea and the underexplored 'rare biosphere'.

Submitted: March 29, 2010; Accepted: August 12, 2010
Proc Natl Acad Sci USA 103:12115-12120

Solomon S, Qin D, Manning M, Alley RB and others (2007) Technical summary. In: Solomon S, Qin D, Manning M, Chen Z and others (eds) Climate change 2007: the physical science basis. Contribution of Working Group I to the 4th Assessment Report of the Intergovernmental Panel on climate change. Cambridge University Press, Cambridge

Steinacher M, Joos F, Frölicher TL, Plattner GK, Doney SC (2009) Imminent ocean acidification projected with the NCAR global coupled carbon cycle-climate model. Biogeosciences 6:515-533

Suffrian K, Simonelli P, Nejstgaard JC, Putzeys S, Carotenuto Y, Antia AN (2008) Microzooplankton grazing and phytoplankton growth in marine mesocosms with increased $\mathrm{CO}_{2}$ levels. Biogeosciences 5:1145-1156

Takeuchi K, Fujioka Y, Kawasaki Y, Shirayama Y (1997) Impacts of high concentration of $\mathrm{CO}_{2}$ on marine organisms; a modification of $\mathrm{CO}_{2}$ ocean sequestration. Energy Convers Manag 38(Suppl 1):S337-S341

> Tanaka T, Thingstad TF, Løvdal T, Grossart HP and others (2008) Availability of phosphate for phytoplankton and bacteria and of glucose for bacteria at different $\mathrm{pCO}_{2}$ levels in a mesocosm study. Biogeosciences 5:669-678

Tortell PD, Rau GH, Morel FMM (2000) Inorganic carbon acquisition in coastal Pacific phytoplankton communities. Limnol Oceanogr 45:1485-1500

Tortell PD, DiTullio GR, Sigman DM, Morel FMM (2002) $\mathrm{CO}_{2}$ effects on taxonomic composition and nutrient utilization in an Equatorial Pacific phytoplankton assemblage. Mar Ecol Prog Ser 236:37-43

> Vega Thurber R, Willner-Hall D, Rodriguez-Mueller B, Desnues C and others (2009) Metagenomic analysis of stressed coral holobionts. Environ Microbiol 11:2148-2163

> Veloza AJ, Chu FLE, Tang KW (2006) Trophic modification of essential fatty acids by heterotrophic protists and its effects on the fatty acid composition of the copepod Acartia tonsa. Mar Biol 148:779-788

Wilhelm SW, Suttle CA (1999) Viruses and nutrient cycles in the sea. Bioscience 49:781-788

Yamada N, Suzumura M, Tsurushima N, Harada K (2008) Impact on bacterial activities of ocean sequestration of carbon dioxide into bathypelagic layers. In: OCEANS'08 MTS/IEEE Kobe-Techno-Ocean'08 - Voyage toward the Future, OTO'08, 8-11 April, Kobe, p 1-3

Proofs received from author(s): October 4, 2010 